\title{
Plastic Mulches to Establish Seedling Asparagus Transplants
}

\section{C.W. Marr and W.J. Lamont, Jr. Department of Horticulture, Kansas State University, Manhattan, KS 66506}

Additional index words. Asparagus officinalis, photodegradable mulches, drip irrigation

Establishment of asparagus by seedling transplants, rather than crowns, offers the advantages of machine transplanting, shortening time in a seedling nursery, reducing crown injury due to separation, lessening the chance of Fusarium sp. infection, making more efficient use of hybrid seed, and improving uniformity of plant stands (Benson et al., 1978; Fisher, 1982; Ombrello and Garrison, 1978). During the establishment year, herbicide alternatives are limited, making plastic mulches useful for in-row weed control with the added benefit of increased growth possibilities. An increase in crown size and buds during the establishment year may increase yields during the following season (Dufault and Greig, 1983). The use of photodegradable mulches may be especially well suited to asparagus production since they will deteriorate during the establishment year and will not interfere with spear emergence in succeeding years. The purpose of this study was to evaluate several plastic mulches in combination with drip irrigation and hybrid asparagus seedling transplants to maximize seedling growth during the establishment year.

Asparagus (Asparagus officinalis L. cv. Jersey Giant) seedling transplants were grown in a greenhouse for 14 weeks and transplanted $5 \mathrm{~cm}$ deep in mulched beds on 10 May 1989. Soil was a coarse-silty mixed, calcareous, mesic Mollic Udifluvent. Plants were spaced $60 \mathrm{~cm}$ apart in $1.5-\mathrm{m}$ rows, with five plants per experimental unit and four replications in a randomized complete-block design. Mulch treatments were: 1) black embossed film, 2) white side exposed/black

Received for publication 20 Feb. 1990. Contribution no. 90-242-J of the Kansas Agr. Expt. Sta. Reference to a product does not imply recommendation to the exclusion of others which may be suitable. The cost of publishing this paper was defrayed in part by the payment of page charges. Under postal regulations, this paper therefore must be hereby marked advertisement solely to indicate this fact. in seedling hybrid asparagus plants. embossed film, 3) Plastigone F131 (Plastigone Technologies, Miami, Fla.), 4) Biolan NV10 (Biolan Corp., Princeton, N.J.) mulch, and 5) an unmulched control. Drip-irrigation tubing was installed in all plots $7 \mathrm{~cm}$ to the side of the row and $5 \mathrm{~cm}$ below the bed surface. Soil was fertilized before planting and through the drip system using recommended commercial production practices. The embossed plastics were nondegrading, while the Plastigone and Biolan films were photodegradable, with Plastigone degradation starting on 12 July and Biolan on 5 July (65 and 58 days after application, respectively). The weather was warm and dry during the early part of the season. Soil water status was measured with tensiometers at 15 - and $30-\mathrm{cm}$ depths in the black plastic-mulched plot and water was applied when soil matric potential at $30 \mathrm{~cm}$ reached $-20 \mathrm{kPa}$.

Mulched plants were higher in mid-July than those not mulched (Table 1), but all were similar in August (91 to $108 \mathrm{~cm}$ ) and September $(120$ to $131 \mathrm{~cm})$. When crowns were dug on 11 Oct., mulched asparagus plants were larger when grown under nondegradable plastics than under degradable plastics. Crown and top weight differences in nondegradable vs. degradable mulches indicated the importance of the standard mulch material in improving soil water status during midsummer, as indicated by Wilcox-Lee
(1987). No differences in top : crown ratio were observed ( 0.97 to 1.07$)$. The number of buds was proportional to crown size, indicating that the following year's spear emergence would be increased in relation to crown size. Crown weight per bud was similar for all treatments (13.3 to $15.4 \mathrm{~g}$ ).

The potential for increasing establishment-year crown size with plastic mulches may be offset by limitations of the shallow planting depth. Asparagus is usually planted in trenches to improve survival and increase spear size. It is unknown how this shallow depth of planting may be adapted to traditional asparagus culture. However, crowns of shallow-planted asparagus develop deeper with time (Loughton and Baker, 1985).

Large crown sizes were produced in a single growing season from seedling transplants using a hybrid cultivar and intensive production techniques involving plastic mulches. This system may offer earlier and greater crop production potential in this perennial crop.

\section{Literature Cited}

Benson, B., F. Souther, F. Takatori, and R. Mullen. 1978. Establishing asparagus plantations with seedling plants. Calif. Agr. 32:10-11.

Dufault, R. and J. Greig. 1983. Dynamic growth characteristics of seedling asparagus. J. Amer. Soc. Hort. Sci. 108(6):1026-1030.

Fisher, K. 1982. Comparison of the growth and development of young seedling asparagus plants established by seedling transplants and direct seeding. N.Z. J. Expt. Agr. 10:405-408.

Loughton, A. and R. Baker. 1985. The effect of depth of direct seeding on asparagus. Proc. Sixth Intl. Asparagus Symp., Univ. of Guelph, Ontario, Canada. 6:355.

Ombrello, T. and S. Garrison. 1978. Establishing asparagus from seedling transplants. HortScience 13(6):663-664.

Wilcox-Lee, D. 1987. Soil matric potential, plant water relations, and growth in asparagus. HortScience 22:22-24.

Table 1. Plastic mulch influence on plant height, top and crown weight, and crown bud development

\begin{tabular}{|c|c|c|c|}
\hline \multirow[b]{2}{*}{ Mulch } & \multirow{2}{*}{$\begin{array}{l}\text { Plant ht } \\
\frac{(\mathrm{cm})}{\text { July }}\end{array}$} & \multicolumn{2}{|c|}{ Fresh wt $(\mathrm{g})$} \\
\hline & & Top & Crown \\
\hline Black embossed (BE) & 78 & 1110 & 1170 \\
\hline White embossed (WE) & 68 & 926 & 998 \\
\hline Biolan NV10 (B) & 66 & 748 & 681 \\
\hline Plastigone F131 (P) & 75 & 722 & 686 \\
\hline None $(\mathrm{N})$ & 57 & 569 & 582 \\
\hline N vs. rest & $* *$ & $* *$ & $*$ \\
\hline BE vs. WE & $* *$ & NS & NS \\
\hline$B E$ and $W E$ vs. $B$ and $P$ & NS & ** & *** \\
\hline B vs. $P$ & $*$ & NS & NS \\
\hline
\end{tabular}

**,* ${ }^{\mathrm{NS}}$ Contrasts significant at $P=0.01,0.05$, or not significant, respectively. 